\title{
Comparative study of the vegetative and generative organs in pear varieties
}

\author{
Dremák, P. ${ }^{1} \&$ Kocsisné Molnár, G. ${ }^{2}$ \\ 'Debrecen University, Faculty of Agriculture, Department of Fruit Growing, Debrecen, Hungary \\ ${ }^{2}$ Veszprém Universuty, Georgicon Faculty of Agriculture, Department of Horticulture, Keszthely, Hungary
}

\begin{abstract}
Summary: An assortment of 17 pear varieties was examined in 2006 at Keszthely, Department of Horticulture, Georgicon Faculty of Agriculture, Veszprem University. The selected varieties were planted in 1980, grafted on seedling rootstock and represented the majority of existing pear plantations in Hungary. The main objective was the determination of suitability of the most important varieties for the purpose of intensive growing technologies even when grafted on vigorous seedling rootstock. The most important growing and fruiting characteristics of the varieties have been assessed and evaluated from the point of view of productivity. We stated that the relations of the trunk or the main axis to the lateral branches and fruiting structures are all subject to varietal effects and are valuable indices of the growing character. The quotient of the diameters of trunk and branch should be around 0.3-0.4, and the relative frequency of fruiting structures (Därda, nyárs, vesszö) meaning the ability of branching and regeneration associated with accurate pruning policies are decisive from the point of view of promising success.
\end{abstract}

Key words: pear (Pyrus communis), varieties, intensive training systems, bearing shoots

\section{Introduction}

The European pear (Pyrus communis) is a relatively susceptible fruit species, but it is grown all over the Hungarian country. Its adaptability, lime tolerance and vigour allows the successful cultivation on pear seedling rootstock. The offer of the Hungarian nurseries is based on grafts of this type at more than $90 \%$ (Hrotkó 1999). The rest of $10 \%$ on quince root being less vigorous is reserved to smaller areas, where irrigation is possible. We have to consider also the graft-incompatibility of certain pear varieties to quince (e.g. Williams, Clapp's Favourite, Bosc Cobak, Dr. Jules Guyot, Alexander Lucas etc.), which could be avoided with intermediate grafts using a compatible pear variety (Haas \& Hildebrandt 1967; Probocskai 1969, Lombard \& Westwood 1987). However, the costs of the graft is increased substantially.

As rootstocks utilised in Hungary are dominated by vigorous seedlings, which is the opposite of the practice adopted in other pear growing countries, where the dwarfing quince is the most utilised rootstock (Hrotkó 1995, Bach et al. 1998). Let alone the adaptability of the variety, the success at the conditions of intense cultivation technologies requires small tree size in order to facilitate interventions (e.g. shoot selection, green pruning, fruit thinning), for the sake of quality and yield security.

In spite of many new varieties, the majority of pears grown is produced mainly by several hundred year old varieties all over the world. As a matter of fact, consumers stick to the old varieties. A good example is the Williams variety, which is on the list since 1770, and it is still the most produced one. In America it is represented at $30-40 \%$. In Italy, the first pear growing country of Europe, the leading variety is Abate Fétel (24.8\%), than Williams (19.8\%), Conference $(16.3 \%)$, Doyenné de Comice $(8.7 \%)$ and Bosc kobak (8.6\%) (Sansavini et al., 1999).

In the Hungarian assortment, we registered at the moment 13 commercial and 21 complementary varieties. According to the volume multiplied by the nurseries, the most important items are Williams $(24.1 \%)$, Bosc kobak (20.3\%), Hardenpont téli vajkörte (13.6\%), Clapp's Favourite (6.1\%) and Hardy vajkörte (6.5\%) (OMMI, 1999).

The fertility and fruiting habits of the varieties differ conspicuously from each other. The site, where the flower buds are formed depends on the variety but also on the age, nutritional status of the tree as well as on the phytotechnical conditions applied (Göndörné, 2000). According to this point of view, the fuiting structures of the tree are assigned to 5 groups:

- Short fruiting body, which is $1-5 \mathrm{~cm}$ long, ending with a well developed mixed bud.

- The smooth spears, 6-20 cm long bears are also a mixed apical bud, whereas the lateral buds are generally leaf buds. Sometimes however the apical bud remains a leaf bud too.

- Medium long fruiting structure is $20-50 \mathrm{~cm}$ long. At the apex and in some of the lateral buds inflorescence. Some of the varieties, as Williams and Packham's Triumph are inclined to develop flowers also in lateral buds.

- Long shoots are longer than $50 \mathrm{~cm}$. They are important mainly on young trees especially in the varieties Williams, Packham's Triumph and Conference. About $80 \%$ of the flower (mixed) buds could appear on those long shoots. Later on, after the $10-15^{\text {th }}$ year, most varieties bear on the short fruiting body and smooth spears. 
- Another short fruiting body is also a typical and important fruiting structure of the pear. The axis of the mixed bud becomes thick with the developing fruit stem and that serves for the development of further fruits of the successive years.

Our examinations are aimed to analyse the growing and fruiting habits of the varieties, as being decisive from the point of view of suitability to intensive growing conditions on pear seedling rootstock.

The success of training to an intensive crown form depends on the growing and fruiting characters of the respective varieties. So we will be able to distinguish varieties according to their inclination to bear fruit even when trained to intense crown forms on vigorous rootstock.

\section{Materials and methods}

The assortment of varieties studied was planted in 1981 at Keszthely by the Department of Horticulture, Georgicon Faculty of Agriculture, Veszprém University. The examinations were performed in 2006 January on the pear trees grafted on seedling rootstock and planted in a system 6.5 $\mathrm{x} 4.0$ meters. The trees were trained to a free spindle form and received moderate pruning since long, i.e. vertical "watershoots", which would inhibit light penetration were cut off only during the rest period. The trees being older than 20 years the tendency of generative growth was characteristic, but differences between varieties were conspicuous.

The varieties examined are listed as follows: Red Williams, Hardy vajkörte, Hardenpont téli vajkörte, Téli esperes, Packham's Triumph, Alexander Lucas, Árpával érö, Red Clapp, Bosc Cobak, Kaiser, Curé, Dr. Jules Guyot, Olivier des Serres, Diel vajkörte, Clapp's Favourite, Conference, Williams.

Each variety was represented by three trees. For the purpose to characterise the growth and the development of fruiting structures, the following traits were assessed:

- circumference of the trunk (at half way between the soil and the first branch, $\mathrm{cm}$ ),

- circumference of the primary lateral branches near to the main axis $(\mathrm{cm})$,

- total length of the branches $(\mathrm{cm})$,

- total number of the growing tips on the branches (short fruiting body, smooth spears, shoots),

- length of shoots (cm).

Those data served to calculate the parameters as for the sake of an objective comparison of varieties:

- the quotient of the diameter of branch and the diameter of the main axis just below the branch (the Zahn-index) $(\mathrm{cm} / \mathrm{cm})$,

- the specific number of growing tips of one branch per cross section area of the branch (tips $/ \mathrm{cm}^{2}$ ),

- the specific number of shoots per cross section area of the respective branch (shoots $/ \mathrm{cm}^{2}$ ),

- the total length of shoots per cross section area of the respective branch $\left(\mathrm{cm} / \mathrm{cm}^{2}\right)$
- the specific number of fruiting structures (short fruiting body and smooth spears) per cross section area of the respective branch (fr.str. $/ \mathrm{cm}^{2}$ )

In some cases the median value of the respective data has been calculated and subsequently the varieties were divided into two distinct groups.

\section{Results and discussion}

The seventeen pear varieties widely grown in Hungary displayed a large scale of variation. The trunk cross section area of pear varieties is presented in Figure 1 .

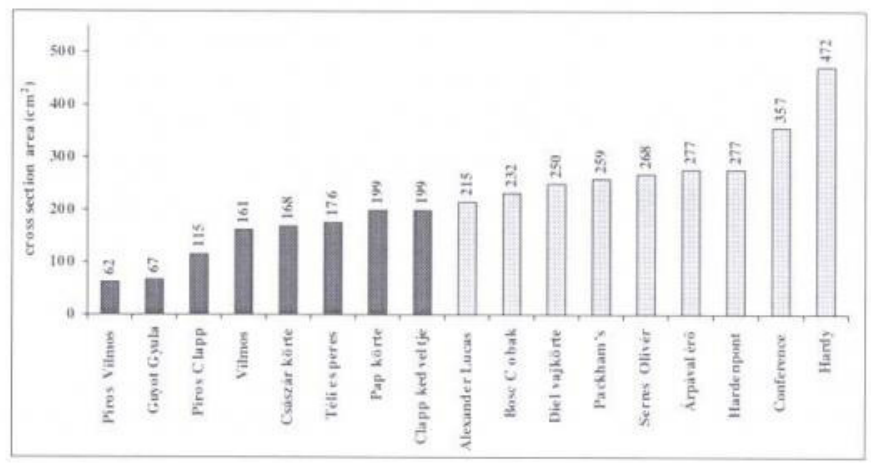

Figure 1. The mean cross section areas of pear varieties examined $\left(\mathrm{cm}^{2}\right)$ (Keszthely, 2006)

According to the cross section area of the trunk, the assortment has been divided into two groups:

- Small cross section areas of the trunk: between 62.4 $\mathrm{cm}^{2}$ and $199 \mathrm{~cm}^{2}$

- The median of the data coincided with the mean value of the Alexander Lucas, i.e. $215.3 \mathrm{~cm}^{2}$

- Large cross section area of the trunk: between 232.2 $\mathrm{cm}^{2}$ and $472.1 \mathrm{~cm}^{2}$.

The cross section area of the trunk represents the vegetative vigour of the varieties. The variety Alexander Lucas was assigned to the "large" group as its value stood nearer to the mean of the large group $(39 \%)$ than to that of the small group $(39 \%)$. As seen on the Figure 1, there is a large scale of values, the difference being 7.5 -fold of the lower end

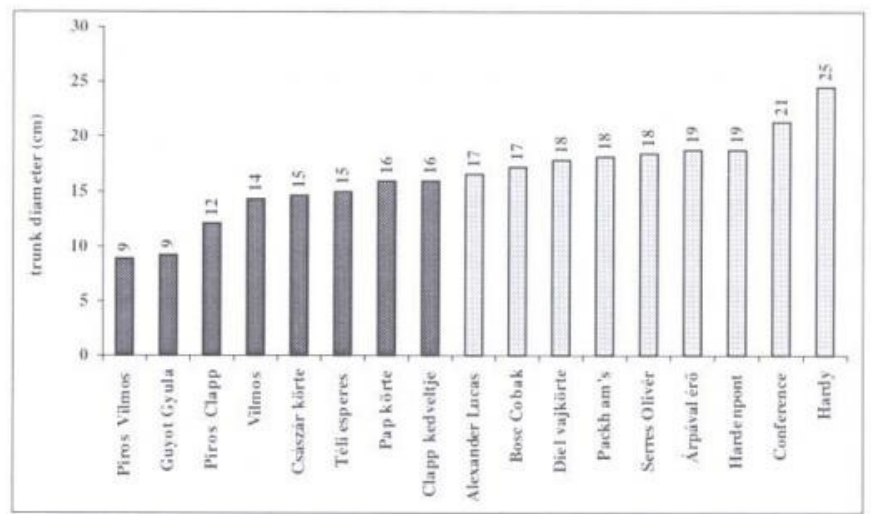

Figure 2. The mean diameter of the trunks according to the varieties (cm) (Keszthely, 2006) 


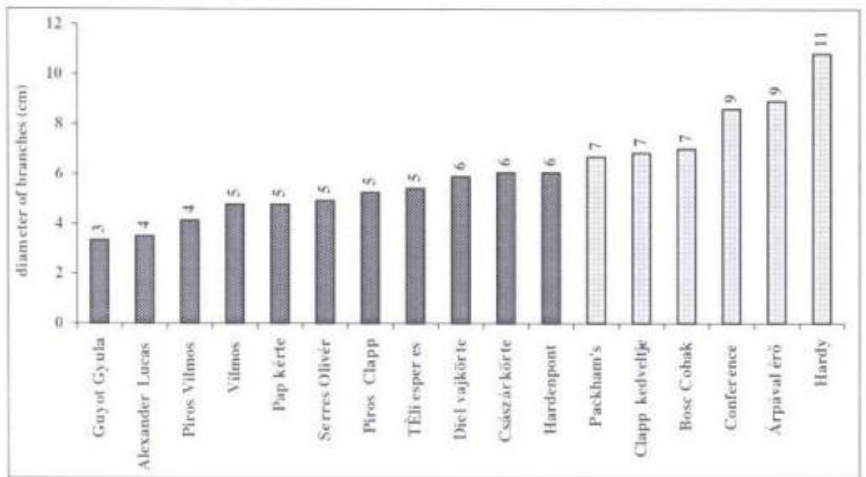

Figure 3. The diameters of branches according to the varieties $(\mathrm{cm})$ (Keszthely, 2006)

between the extremes and with a general mean of $215.9 \mathrm{~cm}^{2}$. The cross section area of the trunk is correlated with the cross section area of the axis above the respective branches. However, there are significant differences between the varieties too. Zahn (1986) stated that the dominance of the main axis is an important condition of the possibility to keep the tree within certain spatial limits within the intensive plantation. The mean diameters of the trunks and the lateral branches are seen in Figures 2 and 3.

In Figures 2 and 3, it is evident that in most cases the large trunk diameters are associated with large branch diameters. Exceptions from this rule are found in Clapp's Favourite, Hardenpont téli vajkörte, Diel vajkörte, Olivier des Serres and Alexander Lucas.

According to the trunk diameter Alexander Lucas (16.6 $\mathrm{cm})$ and those of even larger trunks are listed as members of the large group (Bosc Cobak, Diel vajkörte, Packham's Triumph, Olivier des Serres, Árpával érö, Hardenpont, Conference, Hardy).

Considering the diameters of the branches, Packham's Triumph $(6.7 \mathrm{~cm})$ and those of larger branch diameters are grouped together (Clapp's Favourite, Bosc Cobak, Conference, Árpával érö, Hardy).

In this type of comparison, we may contend that the suitability to intense growing technologies depends on the relatively larger difference between the trunk diameter and the branch diameter even under the conditions of moderate pruning.

Elfving (1996) proposed that the ratio between the active fruiting surface and the passive supporting system (main branches) is closely related to the productivity (fruit bearing). The yearly accumulation of woody material shares the mass of organic matter produced by photosynthesis with the developing fruits, consequently, the fruit yield is limited.

Zahn (1994) compared the diameters of trunk and branches in sweet cherry trees and stated that their optimum ratio is below 0.5 . It is the parameter of a balanced crown. The respective ratios calculated for the pears are shown in Figure 4.

The Zahn indices, i.e. the ratio of branch and main-axis diameters, indicate the deviations from a postulated optimum of balance in the tree crown. The calculate value was around and below 1:0.5. The Figure shows that the index of all varieties was lower than postulated.

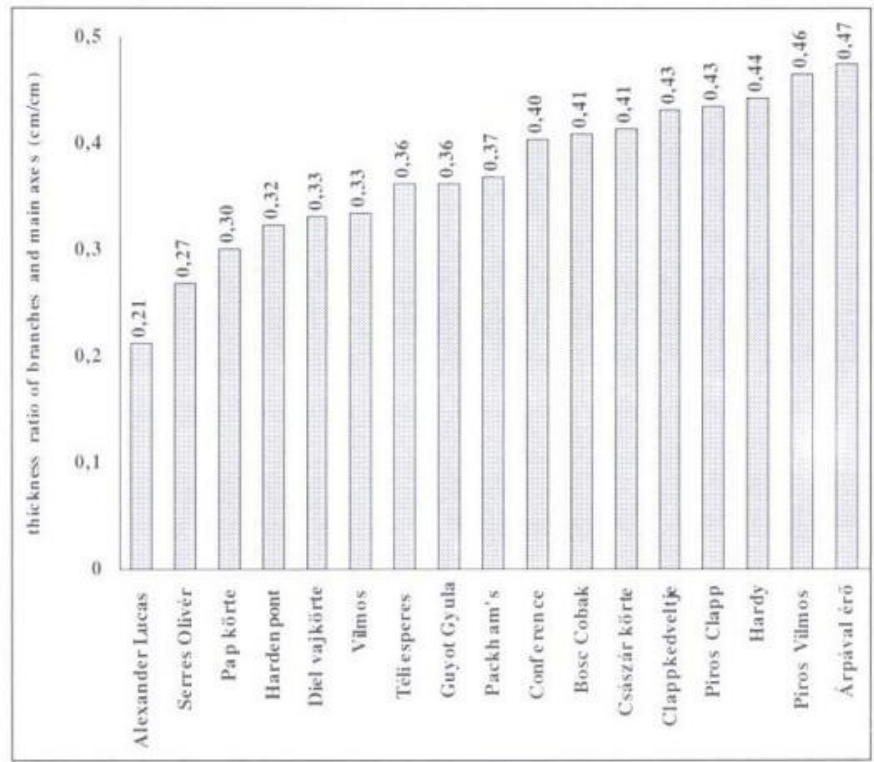

Figure 4. The thickness ratios of branches and main axes obtained in pear varieties $(\mathrm{cm} / \mathrm{cm})$ (Keszthely, 2006)

Principally, all values were more favourable than the suggested optimum for cherry. Other sources reported that values higher than 0.3 are not desirable in Pear varieties. Strydom (1995) stated that the optimum for pear is around 0.3 or even lower than suggested for cherry and for apple by Gonda (2000). On the basis of our data, 0.4 could be determined as favourable.

Following the proposition of Strydom, Alexander Lucas $(0.21)$, Conference $(0.40)$ and the varieties between them are approaching the most the postulated optimum.

From the point of view of intense growing technologies, the relatively thick branches are not favourable. The preponderance of lateral branches over the main axis may threaten the balance of the crown.

However, the large branches alone do not impair the possibility of intense growing technologies as far as many growing tips are found on them. That means many branches on the same structure, which is favourable to keep small trees producing. Within certain limits, it could be encouraged also by accurate pruning policies.

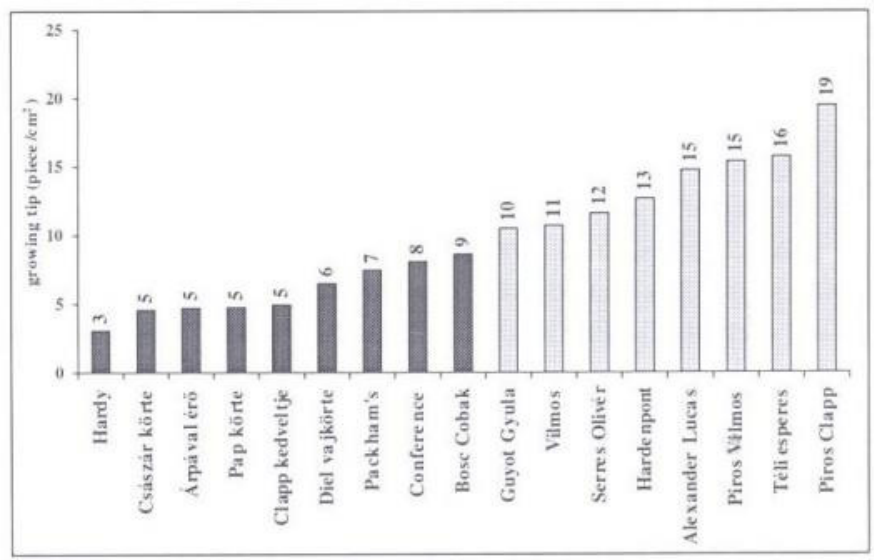

Figure 5 The specific number of growing tips related to the cross section area of the respective branch in pear varieties (tips $/ \mathrm{cm}^{2}$ ) (Keszthely, 2006) 
The number of growing tips is an indication of the branching ability of the respective variety. For the purpose of facilitate an objective comparison, the specific number of growing tips related to the cross section area of the respective branch is calculated (Figure 5).

The calculated median was 9.6. It was most approached by Dr. Jules Guyot. Related to the group means (6.81 and 14.32 ) it belongs to the larger category. The most productive fruiting structures (short fruiting body, smooth spears) deserve special attention and their relative frequency (per $\mathrm{cm}^{2}$ ) is presented in Figure 6.

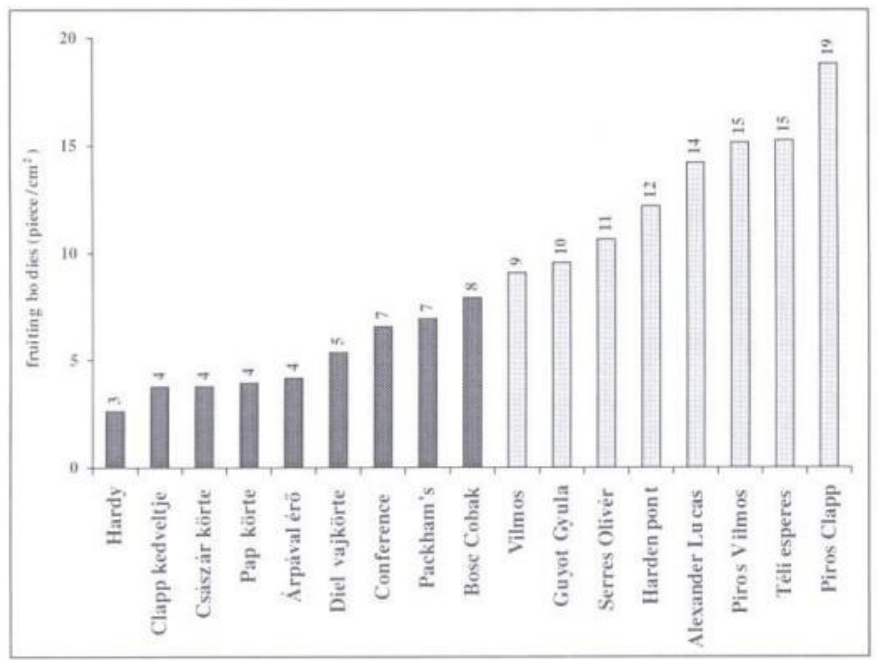

Figure 6. The relative frequency of short fruiting body, smooth spears on the pear varieties (fr.strs/cm2) (Keszthely, 2006)

The Figure calls our attention to the difference, which is between the two extremes 7-fold of the lowest value. The median, 8.33 , was approached by Bosc Cobak, belonging to the group of lower means (4.66), as the mean of the higher value group was 13.44 .

\section{Conclusions and propositions}

Our suggestions are divided into two groups for the sake of easier comprehension. First, the relation of diameters between trunk or central axis and lateral branches are dealt with, subsequently, the branching ability and the number of growing tips will be evaluated.

According to the diameters of trunks and branches (Figures 2 and 3), the following groups are formed:

Variety group 1 :

Thick trunk diameter with slender branches:

- Hardenpont (trunk $\emptyset: 18.8 \mathrm{~cm}$, branch $\varnothing: 6.1 \mathrm{~cm}$ ),

- Serres Olivér (trunk $\varnothing: 18.5 \mathrm{~cm}$, branch $\varnothing: 4.9 \mathrm{~cm}$ ),

- Diel vajkörte (trunk $\varnothing: 17.8 \mathrm{~cm}$, branch $\varnothing: 5.9 \mathrm{~cm}$ ),

- Alexander Lucas (trunk $\varnothing: 16.6 \mathrm{~cm}$, branch

Variety group 2:

Thick trunk with thick branches:

- Hardy vajkörte (trunk $\varnothing: 24.5 \mathrm{~cm}$, branch $\varnothing: 10.8 \mathrm{~cm}$ ),

- Conference (trunk $\varnothing: 21.3 \mathrm{~cm}$, branch $\varnothing: 8.6 \mathrm{~cm}$ ),
- Árpával érô (trunk $\varnothing: 18.8 \mathrm{~cm}$, branch $\emptyset: 8.9 \mathrm{~cm}$ ),

- Packham's Triumph (trunk $\varnothing: 18.2 \mathrm{~cm}$, branch $\varnothing: 6.7 \mathrm{~cm}$ ),

- Bosc Cobak (trunk Ø: $17.2 \mathrm{~cm}$, branch $: 7.0 \mathrm{~cm}$ ).

Variety group 3:

Thin trunk and thin branches:

- Pap körte (trunk Ø: $15.9 \mathrm{~cm}$, branch $\varnothing: 4.8 \mathrm{~cm}$ ),

- Téli esperes (trunk $\varnothing: 15.0 \mathrm{~cm}$, branch $\varnothing: 5.4 \mathrm{~cm}$ ),

- Császár körte (trunkØ: $14.6 \mathrm{~cm}$, branch $0: 6.1 \mathrm{~cm}$ ),

- Vilmos körte (trunk

- Piros Clapp (trunk $: 12.1 \mathrm{~cm}$, branch $\varnothing: 5.3 \mathrm{~cm}$ ),

- Dr. Guyot Gyula (trunk $: 9.2 \mathrm{~cm}$, branch $\varnothing: 3.3 \mathrm{~cm}$ ),

- Piros Vilmos (trunk $\varnothing: 8.9 \mathrm{~cm}$, branch $0: 4.1 \mathrm{~cm}$ ),

Variety group 4:

Thin trunk and thick branches:

- Clapp's Favourite(trunk $\varnothing: 15.9 \mathrm{~cm}$, branch $\varnothing: 6.8 \mathrm{~cm})$,

The fundamental condition of an economical pear production today is the intense growing technology, which requires small trees producing abundant high quality fruit. Varieties belonging to the variety groups 1 and 3 seem to be suitable for developing small trees, which also could be maintained easily. Those are Hardenpont, Olivier des Serres, Diel vajkörte and Alexander Lucas. They develop thick trunks and thin branches, whereas thin trunks and thin branches mean really small trees with low yields (Curé, Téli esperes, Kaiser, Williams, Red Clapp, Dr. Jules Guyot, Red Williams).

The evaluation of pear varieties according to the cross section are and the number of growing tips

The branching potential and the number of growing tips indicate the ability of pear varieties to renew their fruiting structures, consequently, their suitability to be grown by the intense technology without getting bald along the branches. The cross section area of branches and the relatively high number of growing points also could be considered to be decisive from that point of view.

The data presented in Figure 3 on the cross section areas and in Figure 5 on the number of growing points are summarised and compared in Table 1.

The data of Table 1 induce the following conclusions and grouping of varieties

Variety group 1:

Thick branches with a few or intermediate number of growing points, which suggests that an intense growing technology would have likely low chances:

- Hardy vajkörte (branchø: $92.0 \mathrm{~cm}^{2}$ number of growing points: 3.1 gr.p. $/ \mathrm{cm}^{2}$ ),

- Árpával érö (branchø: $62.4 \mathrm{~cm}^{2}$ number of growing points: 4.7 gr.p. $\left./ \mathrm{cm}^{2}\right)$,

- Conference (branch $\varnothing: 58.0 \mathrm{~cm}^{2}$ number of growing points: 8.1 gr.p. $\left./ \mathrm{cm}^{2}\right)$,

Variety group 2:

Medium thickness of branches but few growing points: 
Table 1. The relations between the cross section areas of the lateral branches and the specific (relative) number of growing points per cross section area of the respective branch $\left(\mathrm{cm}^{2}\right.$ and gr.p. $\left./ \mathrm{cm}^{2}\right)$ (Keszthely, 2006)

\begin{tabular}{|c|c|c|c|c|c|c|}
\hline \multirow[t]{2}{*}{ Variety } & \multicolumn{3}{|c|}{$\begin{array}{c}\text { Cross section area of } \\
\text { branches }\left(\mathrm{cm}^{2}\right)\end{array}$} & \multicolumn{3}{|c|}{$\begin{array}{c}\text { Relative number of } \\
\text { growing points } \\
\text { (gr.p. } / \mathrm{cm}^{2} \text { ) }\end{array}$} \\
\hline & $(>20)$ & $(20-40)$ & $(40<)$ & $(>7)$ & $(7-14)$ & $(14<)$ \\
\hline Red Williams & & 13.5 & & & & 15.4 \\
\hline Hardy & & & & 92.0 & 3.1 & \\
\hline Hardenpont & & & 28.7 & & 12.7 & \\
\hline Téli esperes & & & 23.0 & & & 15.7 \\
\hline Packham's & & & 35.1 & & 7.5 & \\
\hline Alexander Lucas & 9.6 & & & & 14.7 & \\
\hline Arpával érö & & & & 62.4 & 4.7 & \\
\hline Red Clapp & & & 21.7 & & & 19.5 \\
\hline Bosc Cobak & & & 38.5 & & 8.6 & \\
\hline Kaiser & & & 28.7 & 4.6 & & \\
\hline Curé & & 17.9 & & 4.7 & & \\
\hline Dr. Jules Guyot & & 8.8 & & & 10.5 & \\
\hline Olivier des Serres & 19.1 & & & 11.6 & & \\
\hline Diel vajkörte & & & 27.2 & & 6.5 & \\
\hline Clapp's Favourite & & 36.8 & & 4.9 & & \\
\hline Conference & & & 58.0 & & 8.1 & \\
\hline Williams & 17.9 & & & & 10.7 & \\
\hline
\end{tabular}

- Diel vajkörte (branchø: $27.2 \mathrm{~cm}^{2}$ number of growing points: 6.5 gr.p. $\left./ \mathrm{cm}^{2}\right)$,

- Kaiser (branchø: $28.7 \mathrm{~cm}^{2}$ number of growing points: 4.6 gr.p. $\left./ \mathrm{cm}^{2}\right)$,

- Clapp's Favourite (branchØ: $36.8 \mathrm{~cm}^{2}$ number of growing points: 4.9 gr.p. $/ \mathrm{cm}^{2}$ ),

Variety group 3 :

Medium thickness of branches with an medium number of growing points, thus branching ability is also intermediate:

- Hardenpont téli vajkörte (branchø: $28.7 \mathrm{~cm}^{2}$ number of growing points: 12.7 gr.p. $\left./ \mathrm{cm}^{2}\right)$,

- Packham's Triumph (branchø: $92.0 \mathrm{~cm}^{2}$ number of growing points: 3.1 gr.p. $\left./ \mathrm{cm}^{2}\right)$,

- Bosc Cobak (branchø: $38.5 \mathrm{~cm}^{2}$ number of growing points: 8.6 gr.p. $\left./ \mathrm{cm}^{2}\right)$,

Variety group 4 :

Medium thickness of branches with high number of growing tips results in a good branching ability:

- Red Clapp (branchø: $21.7 \mathrm{~cm}^{2}$ number of growing points: 19.5 gr.p. $\left./ \mathrm{cm}^{2}\right)$,

- Téli esperes (branchø: $23.0 \mathrm{~cm}^{2}$ number of growing points: 15.7 gr.p. $\left./ \mathrm{cm}^{2}\right)$,

Variety group 5 :

Thin branches with few growing points mean a low branching ability:
- Curé (branchø: $17.9 \mathrm{~cm}^{2}$ number of growing points: 4.7 gr.p. $\left./ \mathrm{cm}^{2}\right)$,

Variety group 6:

Thin branches with many growing points means a very good branching ability:

- Alexander Lucas (branchø: $9.6 \mathrm{~cm}^{2}$ number of growing points: 14.7 gr.p. $/ \mathrm{cm}^{2}$ ),

- Red Williams (branchø: $13.5 \mathrm{~cm}^{2}$ number of growing points: 15.4 gr.p. $\left./ \mathrm{cm}^{2}\right)$

Practical experiences indicate that pear varieties are suitable for intense growing technologies if they fulfil the following requirements:

1 Their crown is prone to be kept within a limited space in the plantation having

- a dominant central axis,

- ather thin lateral branches and generally low cross section areas.

- The number and ratio of fruiting structures are adequate, which secures the regeneration of yielding ability.

\section{References}

Bach I., Bakos J., Göcze L., Munkácsi J., Nagy Á., Paksi E., Szarka Á., Vajdáné K.A. \& Visnyei K. (1998): A gyümölcsfaiskolai ültetvényanyag termesztés tiz éve. OMMI kiadvány, Budapest.

Elfwing (1996): Managing apple tree productivity. Good Fruit Grower, I. 15.

Gonda I. (2000): Minöségi almatermesztés. Primom Kiadó, Nyiregyháza.

Göndörné (2000): Körte. Mezögazda Kiadó, Budapest.

Haas, De. G. \& Hildebrandt, W. (1967): Die Unterlagen und Baumformen des Kern- und Steinobstes. Eugen Ulmer, Stuttgart.

Hrotkó K. (1999): Gyümölesfaiskola. Mezögazda Kiadó, Budapest.

Lombard, P. B. \& Westwood, M. N. (1987): Pear rootstocks. In Rom R. C.-Carlson, R. F. Rootstocks for fruit crops. John Wiley \& Sons, New York. 145-183.

OMMI (1999): Tájékoztatás az elmúlt két évben elöallitott gyümölesfa-iskolai késztermékekröl és az 1999 öszén várható fás és bogyós oltványok becsült mennyiségéröl. OMMI Sokszorositó, Budapest

Probocskai E. (1969): Faiskola. Mezőgazdasági Kiadó, Budapest

Sansavini, S., Lugli, S., \& Rivalta, L. (1999): Pero. Liste varietali dei Fruittiferi 1999. Rivista di Frutticoltura. 9: 22-28.

Strydom, D.(1995): Orchardist of New Zealand. 11 (68) 5: 24-25.

Zahn, F. G. (1986): Intensivierung von Steinobstanlagen durch stärkenbezogene Schnittbehandlung. Erwerbs-Obstbau, (28). 124-140.

Zahn, F. G. (1994): „Höhengerechter Pflanzabstand” durch „Starkbezogene Baumbehandlung”. Erwerbs-Obstbau, 36. (8). 213-220. 